This manuscript is contextually identical with the following published paper: Macfadyen S; Tylianakis JM; Letourneau DK;Benton TG; Tittonell P; Perring M;GómezCreutzberg C; Báldi A; Holland JM; Broadhurst L; Okabe K; Renwick AR; Gemmill-Herren B; Smith HG (2015) The role of food retailers in improving resilience in global food supply. GLOBAL FOOD SECURITY, 7: pp. 1-8. doi:10.1016/j.gfs.2016.01.001

The original published pdf available in this website: http://www.sciencedirect.com/science/article/pii/S2211912416300025

\title{
The role of food retailers in improving resilience in global food supply
}

Sarina Macfadyen ${ }^{1}$, Jason M. Tylianakis ${ }^{2,3}$, Deborah K. Letourneau ${ }^{4}$, Tim G. Benton ${ }^{5}$, Pablo Tittonell ${ }^{6}$, Michael Perring ${ }^{7,8}$, Carla Gómez-Creutzberg ${ }^{2}$, András Báldi ${ }^{9}$, John M. $^{2}$ Holland $^{10}$, Linda Broadhurst ${ }^{11}$, Kimiko Okabe ${ }^{12}$, Anna R. Renwick ${ }^{13}$, Barbara GemmillHerren $^{14}$, Henrik G. Smith ${ }^{15}$

1. CSIRO Agriculture Flagship, Acton ACT, 2601, Australia

2. Centre for Integrative Ecology, University of Canterbury, Christchurch 8140, New Zealand.

3. Department of Life Sciences, Imperial College London, Silwood Park Campus, Ascot, Berkshire SL5 7PY, United Kingdom

4. Department of Environmental Studies, University of California, Santa Cruz, CA 95064 USA

4 5. School of Biology, University of Leeds, LS2 9JT, UK 
25 6. Farming Systems Ecology, Wageningen University, P.O. Box 430 - 6700 AK, The

26 Netherlands

27 7. School of Plant Biology, The University of Western Australia, Crawley WA 6009,

28 Australia

29 8. Forest \& Nature Lab, Ghent University, BE-9090, Gontrode-Melle, Belgium

30 9. Lendület Ecosystem Services Research Group, MTA Centre for Ecological Research, 2-4

31 Alkotmány u. Vácrátót, 2163 Hungary

32 10. Game \& Wildlife Conservation Trust, Fordingbridge, Hampshire, SP6 1EF,UK

33 11. CSIRO National Research Collections and Facilities, Acton ACT, 2601, Australia

34 12. Forestry and Forest Products Research Institute, Tsukuba, Ibaraki 305-8687, Japan

35 13. ARC Centre of Excellence for Environmental Decisions, the NERP Environmental

36 Decisions Hub, Centre for Biodiversity \& Conservation Science, University of Queensland,

37 Brisbane, Queensland 4072, Australia.

38 14. Food and Agriculture Organization of the United Nations, Rome, 00153, Italy

39 15. Department of Biology and Centre of Environmental and Climate Research, Lund

40 University, 22100 Lund, Sweden

41

42

43

44

45

46 


\section{Abstract}

55 We urgently need a more resilient food supply system that is robust enough to absorb and

56 recover quickly from shocks, and to continuously provide food in the face of significant

57 threats. The simplified global food supply chain we currently rely upon exacerbates threats

58 to supply and is unstable. Much attention has been given to how producers can maximise

59 yield, but less attention has been given to other stakeholders in the supply chain.

60 Increasingly, transnational food retailers (supermarkets) occupy a critical point in the chain,

61 which makes them highly sensitive to variability in supply, and able to encourage change of

62 practice across large areas. We contend that the concentration in the chain down to a few

63 retailers in each country provides an opportunity to increase resilience of future supply

64 given appropriate, scale-dependent interventions. We make ten recommendations aimed at

65 reducing variability in supply that can be driven by retailers (although some of the

66 interventions will be implemented by producers). Importantly, resilience in our food supply

67 requires the restoration and expansion of ecosystem services at the landscape-scale.

68 


\section{Keywords}

70 Vulnerability, resilience, ecosystem services, sustainable intensification, landscape,

71 supermarkets

72

73

74

75

$76 \quad$ Highlights

77 - The global food supply system we currently rely upon is unstable.

78 Changes to production practices are necessary to increase resilience to threats.

79 - Retailers are ideally placed to mandate for change across large areas.

80 - Resilience in our food supply requires the restoration of ecosystem services.

81

82

83

84

85

86

87

88

89

90 
99 Our daily lives increasingly depend on a well-functioning global food production and delivery system. With rapid population growth in some regions, demographic and geo-

101 political change, set against changing climate patterns and extremes, resilience of global 102 food supply is paramount. Even small shocks early in the supply chain can amplify through 103 the global agri-food system impacting people who are geographically distant from the 104 disturbance (Puma et al., 2015; Suweis et al., 2015). For example, a drought period in 105 2007-08, coupled with low stocks and export restrictions, led to food price inflation 106 sparking food riots in many places (Berazneva and Lee, 2013; Galtier, 2013). Significant 107 crop (and post-harvest) losses due to weeds, invertebrate pest and disease outbreaks have 108 continued over the last 40 years, despite increased use of pesticides (Oerke, 2005; Stokstad, 109 2013). Additionally, many countries have reached the limit of available land suitable for 110 agricultural, with significant areas of this land now so degraded that returning it to 111 productivity will be both difficult and costly (Smith, 2013; Strassburg et al., 2014). Without 112 adaptive changes to the global agri-food system, climate change is expected to reduce crop 
113 yields in regions that are required to produce more in the future, and to increase variability

114 in productivity in other regions (Challinor et al., 2014; Wheeler and von Braun, 2013).

116 We urgently need a more resilient food supply system that is robust enough to absorb and

117 recover quickly from shocks, and continuously provide food in the face of significant

118 internal and external threats (Suweis et al., 2015, see text box 1). These threats range from

119 local factors such as pest outbreaks, pesticide resistance, extreme weather events, and

120 political instability, to global threats such as climate change and changes in land use. In

121 addition, threats outside the supply system (in the demand chain, Gilbert 2010) can interact

122 and lead to price variability. Inputs such as water and agrochemicals are currently over-

123 used in many production contexts whilst pesticide and antibiotic resistance threatens the

124 effectiveness of these inputs. Increased reliance on inputs at the expense of natural

125 ecosystem processes increases environmental externalities (Pretty et al., 2001), but also

126 makes farming more vulnerable to changes that influence the price and availability of

127 inputs. Without significant changes these factors may induce increased spatial and temporal

128 variability in future food supply.

129

130 The purpose of our article is to highlight ways in which stakeholders along the food supply

131 chain can contribute to reducing production variability by adopting more sustainable

132 practices. We focus on the role of retailers, as they provide the link between producers and

133 consumers, and therefore have an ability to influence decision-making at both ends of the

134 food supply chain. Furthermore, their reach has increased in recent years in terms of 
135 accessibility for consumers in developing countries, and sourcing products or ingredients

136 from producers around the world. We highlight 10 practical recommendations to improve

137 resilience in food supply systems to a range of threats. The conceptual foundations of

138 resilience in ecology are often applied to agro-ecosystems (text box 1), and here we use that

139 foundation to explore ways in which we can reduce production variability. One of our main

140 conclusions is that implementing certain intervention strategies at the landscape-scale is

141 necessary to achieve the desired outcomes.

142

\section{Characteristics of our current global food supply system}

144 The food supply chain consists of many inter-connected stakeholders (producers,

145 processors, packagers, distributors, transportation companies, wholesalers, supermarket

146 retailers and consumers, Fig. 1) who will all benefit from, and must contribute to, a more

147 resilient global food supply system. The simplified global food supply chain we currently

148 rely upon exacerbates threats and is potentially highly unstable. This supply chain, which

149 producers around the world deliver into (Fig. 2), encourages uniform production practices

150 (Allison and Hobbs, 2004) that are highly efficient in "good years" but can also be

151 maladaptive under changing conditions (Bennett et al., 2014). For example, inputs such as

152 pesticides are often used to protect crops from damage, regardless of whether a pest is

153 present, or if the overall risk of pest outbreaks has reduced due to climate change. Changing

154 production practices, to those that are more sustainable using the recommendations we

155 outline below, but may carry more risk for the producer in the short-term. Therefore, it is 
156 important that other stakeholders in the chain understand these risks and do not leave it up

157 to producers along to bring about change.

159 Food retailers occupy a critical point in the food supply chain (Fig. 1), which makes them

160 highly sensitive to variability in supply, and well-positioned to encourage change of

161 practice across large areas (Burch et al., 2012; Konefal et al., 2005). There has been a

162 "supermarket revolution" especially in developing countries over the past 20 years

163 (although this has only just started in parts of Africa) (Reardon et al., 2012). As an

164 example, in Thailand about $85 \%$ of people now have access to, and regularly purchase food

165 from, supermarkets, compared to $47 \%$ ten years ago (Kelly et al., 2014). There has been a

166 concentration and multinationalizing of retailers (Burch et al., 2012, and also processing

167 and wholesale stakeholders, Reardon 2015). We contend that the concentration in the chain

168 down to a few retailers in each country provides an opportunity to increase resilience of

169 future supply given appropriate, scale-dependent interventions.

171 Many valid recommendations have been made for increasing food supply and reducing 172 waste, and there is growing recognition that despite adequate food production, inequity in 173 distribution ensures that malnutrition persists (Godfray et al., 2010). However, much of the 174 focus of the global food security discourse has recently been about growing average yields, 175 and has emphasized the role of highly productive, large-scale agriculture systems without 176 much regard to their vulnerability to external shocks (McKenzie and Williams, 2015; Shen 177 et al., 2013). Thus, our specific focus here is on reducing variability in production as a 
178 consequence of changing environmental, social, and market conditions since this variability

179 has the potential to cause significant social and economic impacts (see text box 1).

180 Resilience to threats in our food supply system, we contend, is often crucially related to

181 under-pinning ecological functions that allow for enhanced delivery of ecosystem services

182 within sustainable agri-food system (Bennett et al., 2014; Yachi and Loreau, 1999).

\section{Resilient food systems necessitates a landscape-scale perspective}

185 To increase resilience of production and supply, stakeholders should encourage, and in

186 some cases mandate, sustainable practices with an emphasis on co-ordination at the

187 landscape-scale (text box 2). Success of such practices frequently requires their

188 implementation at the landscape-level. For example, area-wide pest management is

189 required for: effective deployment of insect mating confusion pheromones, the removal of

190 alternative host plants or sources of weed seeds, the maintenance of non-transgenic or

191 unsprayed refugia for susceptible pest genotypes that delay the development of pesticide

192 resistance, and the maintenance of vegetative habitat to support viable populations of

193 arthropods that provide pollination and pest control services (Tscharntke et al., 2005).

194 Longer-term interventions that improve ecosystem services such as water purification,

195 flood control, and soil erosion prevention also need to be implemented at landscape-scale or 196 greater to achieve the desired outcomes for sustainable food supply (Rodriguez-Loinaz et

197 al., 2015). Government-directed policy initiatives often struggle to implement change at the 198 landscape-scale (and in a global market) and instead focus on individual landowners to 199 effect change. 
201 Landscape-scale management requires local collaboration among landowners, which can

202 otherwise be threatened by the 'tragedy of the commons' or lack of mechanisms for

203 collective decision-making (Lant et al., 2008). We argue that food retailers operate at the

204 interface between producers and consumers and consequently, hold a critical position to

205 overcome this dilemma and influence production practices at the landscape scale (Jennings

206 et al., 2015), while also shaping consumer attitudes to environmental costs of production,

207 and thereby increasing demand for sustainable products (Lazzarinin et al., 2001). Consumer

208 access to food through supermarkets has increased dramatically in recent years (Kelly et al.,

209 2014), yet in some countries only a few food retailers sell to consumers (Fig. 1). This

210 concentration of source products or ingredients from thousands of producers and traders

211 around the world (Fig. 2), through a limited number of retailers, thus provides an

212 opportunity for them to improve resilience to shocks in food supply.

\section{Recommendations to improve resilience}

215 We highlight 10 recommendations that can be implemented by stakeholders along the

216 supply chain (Fig. 1), to reduce variability in supply and improve recovery from shocks.

217 Examples of interventions based on existing knowledge and technologies that support these

218 recommendations are given in Table 1 . We focus just on these ten as they have significant

219 research underpinning them (as identified by conversations amongst the authors), and are

220 likely to improve sustainability and resilience across a range of farming systems. Retailers

221 are well equipped to proactively maintain predictable flows of produce by implementing (or 
222 incentivising producers and consumers to implement) many of these recommendations, and

223 this is likely to improve the resilience of their business and the sustainability of agricultural

224 production. Likewise retailers can influence consumer decision-making at a range of scales

225 to re-inforce sustainable production practices. Some retailers already have existing

226 sustainability standards and some of our recommendations will be encompassed by these

227 (but see text box 1). Our recommendations are:

1. Mandate practices that maintain and restore soil resources. Global degradation of soils

230 threatens food supply. However, regenerative management interventions have

231 demonstrated potential to improve soil-microbe interactions, increase yields and ensure

232 sustained high productivity that is less vulnerable to the extremes of water logging and

233 drought, with the additional benefit of helping to mitigate climate change by increasing

234 soil organic carbon (Alliaume et al., 2014; Holland, 2004; Lal, 2004).

235 2. Protect water resources. Increased variability in rainfall, reduced water quality and

236 increased competition for water resources threaten the production of irrigation-

237 dependent crops (Mancosu et al., 2015). To prevent water-borne contamination of

238 produce, or human conflict under extreme water scarcity, interventions include rainwater

239 capture and storage, conservation tillage, vegetative buffers against agricultural run-off

240 entering waterways, and expansion of efficient irrigation infrastructure.

241 3. Identify marginal or low productivity land and encourage its removal from high-input

242 production. Degraded and less productive parcels of land with high input costs relative

243 to yields can be conserved to support the environmental benefits increasingly demanded 
by society. Connectivity of these patches at the regional-level supports producers' social licence to operate and benefits biodiversity-based ecosystem services. We should investigate strategies for integrating these areas across the landscape, and using them to create multifunctional agricultural landscapes (Renting et al., 2009).

4. Ensure producers use agrochemicals judiciously. Reduced pesticide-use reduces the evolution of pesticide resistance in insects and weeds (Stokstad, 2013), harm to non-target organisms, environmental contamination (Pelosi et al., 2013), and residues on food.

251 Consumer demand for reduced health risks will require producers to adopt strategies that 252 replace chemical inputs, where possible, with the activities of naturally occurring ecosystem service providers as in conservation biological control and adoption of area-wide

254 pest management strategies against mobile pathogens. Increased nutrient-use efficiency and 255 better targeting of nutrient input to areas where nutrient deficiency is recognized as the 256 limiting factor has the potential to reduce farmer costs and limit runoff into waterways 257 (Grafton and Yule, 2015).

5. Encourage landscape-scale diversification. A diverse crop portfolio protects farmers

259 from price- and environmental-volatility and provides trade opportunities for 260 smallholder farmers, thereby helping to ensure farm business resilience (Abson et al., 261 2013). Moreover, landscapes that integrate crop, livestock and forestry systems with 262 natural set-aside areas experience a higher, and more resilient, provision of ecosystem 263 services such as crop pollination and pest control (Kremen and Miles, 2012; Liebman 264 and Schulte, 2015; Tscharntke et al., 2005). Finally, diverse landscapes improve the 
efficiency of resource flows among landscape components, such as winter feed for stock or use of stock manure as fertiliser.

6. Encourage sustainable livestock management practices. Global demand for livestock produce is growing. Supplying this demand means meeting increasing consumer demand

7. Identify future crops and products and help prepare farmers. As climate changes make some crops non-viable in certain regions, production may need to shift to new crops, forage plants and livestock breeds that are better-suited to future conditions (e.g. bambara nuts, moringa, perennial grains), or to "rediscovered" traditional agricultural products that can be marketed to a new generation of consumers. Perennial cultivation, with many benefits for soil health and sustainability, will need a careful and supportive articulation with markets (and consumers), differing from annual production systems that can more readily switch crop-types (FAO, 2013). Often producers have already identified potential new products, but require support to develop them into marketable commodities.

8. Support the farmers of the future. The average age of farmers is increasing in many countries as young people migrate to urban areas or face professional barriers (e.g., land 
prices and availability). Whilst this issue goes beyond food retailers, there is a critical need for retailers to recognise the impact of this shift on the resilience of their business. Interventions include encouraging support networks for farmers, ensuring that the rural way of life is profitable (through fair pricing), lobbying governments to support sustainable land tenure agreements, and encouraging retailers to better understand farmers aspirations and production constraints (de Snoo et al., 2013; Farmar-Bowers, 2010).

9. Identify products (and their ingredients) that are produced in high-risk regions. Risks of disrupted supply in some regions may be generated by local environmental (e.g. climate change) or social/political instability (Lagi et al., 2011) (Fig. 2). Solutions will require either policy mechanisms to reduce risks, production specifically tailored to build local sustainability and resilience to withstand environmental risks (Rossing et al., 2014), or carefully planned alternative sourcing by retailers and food manufacturers from a wider spectrum of producers.

\section{Identify products (and their ingredients) that have costly environmental externalities}

- mitigate these externalities. Trade-offs between increased productivity and the environment may negatively feedback to production and ultimately generate an unsustainable and low-resilience supply (e.g., through soil degradation, loss of pollination services, inefficient water use) (Matson et al., 1997). In some cases this could be ameliorated through improved management practices; in others, product substitution must be considered. True cost accounting, including the cost of negative externalities in the prices of agricultural produce, is one means of creating incentives for change (Pretty 
et al., 2001). Importantly, consumers should have access to the provenance, and estimated environmental costs, of products and ingredients in products sold by retailers, so they can make informed choices.

\section{The role of retailers}

314 The fundamental basis of many of the 10 recommendations is the restoration and expansion 315 of ecosystem services in agricultural landscapes. Encouraging producers to move away 316 from input-driven agricultural decision-making is challenging and retailers have a role to 317 play in this transition process. Retailers have the power to issue production mandates that can lead to wide-scale change of practice. The scale of implementation of these production mandates and specific interventions (e.g., Table 1) is critical, as is the farming context in which they take place. Crop failures occur when mutually disruptive practices are

321 employed in individual farming operations, such as monocultures that homogenize 322 resources for specific pest species, landscape-wide use of the same varieties that facilitate 323 disease spread, uniform spray tactics that harm pollinators and soil biota and select for 324 pesticide resistance, or planting times that assist pest or pathogen build-up. Coordinated, 325 long-term interventions are necessary for sustaining the provision of ecosystem services 326 that buffer against these threats. Importantly, some of these interventions can be 327 implemented now through relatively simple changes. For example, many strawberry 328 producers in California still use methyl bromide soil fumigants to control diseases, 329 nematodes and weeds, despite it being banned in other crops. The transition away from this practice is foreseeable, and is already taking place through individual growers who have 
331 begun to implement anaerobic soil disinfection, a promising alternative treatment involving

332 microbial shifts after carbon inputs and flooding (Butler et al., 2014). Encouraging all

333 growers to find alternative approaches could be aided by purchase premiums offered by

334 retailers and associated education of consumers.

336 Standards and policies dictated by retailers already have a global reach, influencing 337 production practices in terms of food safety, quality and environmental impacts (Burch et 338 al., 2012). However, many small-scale producers cannot meet standards or price points, and 339 must operate independently using local markets (Konefal et al., 2005). These local markets 340 should be viewed as collaborators, not competitors of big retailers. In many instances, local 341 markets use complementary food distribution systems such as food hubs, community342 supported agriculture or farmers' markets. Farmer to farmer movements and agroecological

343 farming models support local consumption and export crops in parallel supply chains

344 outside of the mainstream markets, and may provide innovative examples for resilience in 345 the face of climate change and market fluctuations (Babin, 2014). In addition smallholder

346 farmers in certain contexts may require different management strategies to improve 347 resilience to shocks that we have not addressed properly here.

\section{Conclusions}

350 Our food supply system needs to be and can be made more resilient through the 351 implementation of appropriate interventions at the appropriate scale, but this should not be 352 left up to producers or government policy alone. Stakeholders, such as global food retailers 
353 and consumers, also have a key role to play in ensuring resilience in our global food supply

354 system to a range of current and future threats. If the 10 recommendations outlined here

355 were adopted as a road map for resilience by transnational retail companies there would be

356 significant changes in the way large areas of agricultural land are managed in the future.

357 These recommendations may also help shift consumer perceptions around the true costs

358 certain products. These interventions, based on currently available knowledge and

359 technology, could lead to more sustainable agricultural landscapes over a relatively short

360 time frame.

361

362 Acknowledgements

363 This paper was developed as part of workshop hosted by CSIRO in Brisbane sponsored by

364 the Organisation for Economic Co-operation and Development's (OECD) Co-operative

365 Research Programme on Biological Resource Management for Sustainable Agricultural

366 Systems. In addition to the authors, Gary Fitt, Nancy Schellhorn, and Saul Cunningham

367 were also involved in discussions that led up to this paper. JMT and CG are funded by the

368 Ministry of Business, Innovation and Employment, NZ (C09X1307) and JMT by a

369 Rutherford Discovery Fellowship. KO is by the Environment Research and Technology

370 Development Fund (S-9) of the Ministry of the Environment, Japan. AB is funded by the

371 MTA Lendület program, LIBERATION FP7 project and the Hungarian Scientific Research

372 Fund (OTKA NN101940). HGS was funded by Formas and LIBERATION FP7. MPP was

373 partially supported by an ARC Laureate Fellowship awarded to R.J. Hobbs. Daniel

374 Macfadyen was instrumental in the graphic design of the figures. The icons in the figures 
375 were made by "Freepik" and downloaded from http://www.flaticon.com under a Creative

376 Commons 3.0 license.

\section{References}

379 Abson, D.J., Fraser, E.D.G., Benton, T.B., 2013. Landscape diversity and the resilience of

380 agricultural returns: a portfolio analysis of land-use patterns and economic returns from lowland 381 agriculture. Agriculture \& Food Security 2, 2.

382 Alliaume, F., Rossing, W.A.H., Tittonell, P., Jorge, G., Dogliotti, S., 2014. Reduced tillage and 383 cover crops improve water capture and reduce erosion of fine textured soils in raised bed tomato 384 systems. Agriculture, Ecosystems \& Environment 183, 127-137.

385 Allison, H.E., Hobbs, R.J., 2004. Resilience, adaptive capacity, and the "Lock-in Trap" of the 386 Western Australian agricultural region. Ecology and Society 9, 3.

387 Babin, N., 2014. The coffee crisis, fair trade, and agroecological transformation: impacts on land388 use change in Costa Rica. Agroecology and Sustainable Food Systems 39, 99-129.

389 Beddington, J., Asaduzzaman, M., Fernandez, A., Clark, M., Guillou, M., Jahn, M., Erda, L., 390 Mamo, T., Bo, N.V., Nobre, C.A., Scholes, R., Sharma, R., Wakhungu, J., 2012. Achieving food 391 security in the face of climate change. CGIAR Research Program on Climate Change, Agriculture 392 and Food Security (CCAFS). Copenhagen, Denmark.

393 Bennett, E., Carpenter, S.R., Gordon, L.J., Ramankutty, N., Balvanera, P., Campbell, B., Cramer, 394 W., Foley, J., Folke, C., Karlberg, L., Liu, J., Lotze-Campen, H., Mueller, N.D., Peterson, G.D., 395 Polasky, S., Rockström, J., Scholes, R.J., Spierenburg, M., 2014. Toward a more resilient 396 agriculture. Solutions 5, 65-75.

397 Berazneva, J., Lee, D.R., 2013. Explaining the African food riots of 2007-2008: An empirical 398 analysis. Food Policy 39, 28-39. 
Burch, D., Dixon, J., Lawrence, G., 2012. Introduction to symposium on the changing role of supermarkets in global supply chains: from seedling to supermarket: agri-food supply chains in transition. Agriculture and Human Values 30, 215-224.

402 Butler, D.M., Kokalis-Burelle, N., Albano, J.P., McCollum, T.G., Muramoto, J., Shennan, C., 403 Rosskopf, E.N., 2014. Anaerobic soil disinfestation (ASD) combined with soil solarization as a 404 Methyl Bromide Alternative: Vegetable Crop Performance and Soil Nutrient Dynamics. Plant and 405 Soil 378, 365-381.

406 Challinor, A.J., Watson, J., Lobell, D.B., Howden, S.M., Smith, D.R., Chhetri, N., 2014. A metaanalysis of crop yield under climate change and adaptation. Nature Climate Change 4, 287-291. de Snoo, G.R., Herzon, I., Staats, H., Burton, R.J.F., Schindler, S., van Dijk, J., Lokhorst, A.M., Bullock, J.M., Lobley, M., Wrbka, T., Schwarz, G., Musters, C.J.M., 2013. Toward effective nature conservation on farmland: making farmers matter. Conservation Letters 6, 66-72. Eisler, M.C., Lee, M.R.F., Tarlton, J.F., Martin, G.B., Beddington, J., Dungait, J.A.J., Greathead, H., Liu, J., Mathew, S., Miller, H., Misselbrook, T., Murray, P., Vinod, V.K., Van Saun, R., Winter, M., 2014. Agriculture: Steps to sustainable livestock. Nature 507, 32-34.

414 FAO, 2008. An introduction to the basic concepts of food security. FAO Food Security Programme. 415 FAO, 2013. Perennial crops for food security proceedings of the FAO expert workshop, in: Batello, 416 C., Wade, L., Cox, S., Pogna, N., Bozzini, A., Choptiany, J. (Eds.). FAO, Rome, Italy.

417 Farmar-Bowers, Q., 2010. Why farming families decide to maintain native biodiversity on their 418 farms and the implications of demographic change for conservation policies, in: Luck, G.W., Black, 419 R., Race, D. (Eds.), Demographic change in Australia's rural landscapes, pp. 233-257.

420 Folke, C., Carpenter, S.R., Walker, B., Scheffer, M., Chapin, T., Rockström, J., 2010. Resilience 421 thinking: integrating resilience, adaptability and transformability. Ecology and Society 15, 20.

422 Galtier, F., 2013. Managing food price instability: Critical assessment of the dominant doctrine. 423 Global Food Security 2, 72-81. 
424 Gilbert, C.L., 2010. How to Understand High Food Prices. Journal of Agricultural Economics 61, $425 \quad 398-425$.

426 Godfray, H.C.J., Beddington, J.R., Crute, I.R., Haddad, L., Lawrence, D., Muir, J.F., Pretty, J.,

427 Robinson, S., Thomas, S.M., Toulmin, C., 2010. Food security: the challenge of feeding 9 billion 428 people. Science $327,812-818$.

429 Grafton, M., Yule, I., 2015. The role of technology transfer to improve fertiliser use efficiency.

$430 \quad$ Food Sec. 7, 365-373.

431 Holland, J.M., 2004. The environmental consequences of adopting conservation tillage in Europe:

432 reviewing the evidence. Agriculture, Ecosystems \& Environment 103, 1-25.

433 Holling, C.S., 1973. Resilience and stability of ecological systems. Annual Review of Ecology and 434 Systematics 4, 1-23.

435 Hoogervorst, N., van Veen, M., Dassen, T., 2012. The assessment of the human environment. PBL

436 Netherlands Environmental Assessment Agency, The Hague. Can be accessed at:

437 http://themasites.pbl.nl/balansvandeleefomgeving/2012/

438 Jennings, S., Miller, S., McCosker, A., 2015. Landscape collaboration for sustainable land use.

439 National Centre for Universities and Business, London, p. 37. Can be accessed at:

440 http://www.ncub.co.uk/reports/fe-land-report.html

441 Kelly, M., Seubsman, S., Banwell, C., Dixon, J., Sleigh, A., 2014. Thailand's food retail transition:

442 supermarket and fresh market effects on diet quality and health. British Food Journal 116, 1180-

4431193.

444 Konefal, J., Mascarenhas, M., Hatanaka, M., 2005. Governance in the global agro-food system:

445 Backlighting the role of transnational supermarket chains. Agriculture and Human Values 22, 291-

446302.

447 Kremen, C., Miles, A., 2012. Ecosystem services in biologically diversified versus conventional

448 Farming systems: Benefits, externalities, and trade-offs. Ecology and Society 17. 
Lagi, M., Bertrand, K.Z., Bar-Yan, Y., 2011. The food crises and political instability in North

450 Africa and the Middle East. New England Complex Systems Institute, Cambridge, USA.

451 Lal, R., 2004. Soil carbon sequestration impacts on global climate change and food security.

452 Science 304, 1623-1627.

453 Lant, C.L., Ruhl, J.B., Kraft, S.E., 2008. The tragedy of ecosystem services. BioScience 58, 969.

454 Lazzarinin, S.G., Chaddad, F.R., Cook, M.L., 2001. Integrating supply chain and network analyses:

455 The study of netchains. Chain and network science 1, 7-22.

456 Liebman, M., Schulte, L.A., 2015. Enhancing agroecosystem performance and resilience through

457 increased diversification of landscapes and cropping systems. Elementa Sceince of the

458 Anthropocene 2.

459 Mancosu, N., Snyder, R., Kyriakakis, G., Spano, D., 2015. Water scarcity and future challenges for 460 food production. Water 7, 975-992.

461 Martin, G.B., Greeff, J.C., 2011. Genetic frontiers in the development of 'clean, green and ethical'

462 management systems for the extensive sheep industry. Proceedings of the 19th Conference of the

463 Association for the Advancement of Animal Breeding and Genetics, Perth. Association for the

464 Advancement of Animal Breeding and Genetics, 19, 143-150.

465 Matson, P.A., Parton, W.J., Power, A.G., Swift, M.J., 1997. Agricultural intensification and

466 ecosystem properties. Science 277, 504-509.

467 McKenzie, F., Williams, J., 2015. Sustainable food production: constraints, challenges and choices

468 by 2050. Food Sec. 7, 221-233.

469 Oerke, E.C., 2005. Crop losses to pests. The Journal of Agricultural Science 144, 31.

470 Pelosi, C., Toutous, L., Chiron, F., Dubs, F., Hedde, M., Muratet, A., Ponge, J.F., Salmon, S.,

471 Makowski, D., 2013. Reduction of pesticide use can increase earthworm populations in wheat crops 472 in a European temperate region. Agriculture, Ecosystems \& Environment 181, 223-230. 
Pretty, J., Brett, C., Gee, D., Hine, R., Mason, C., Morison, J., Rayment, M., Bijl, G.v.d., Dobbs, T.,

474 2001. Policy challenges and priorities for internalizing the externalities of modern agriculture.

475 Journal of Environmental Planning and Management 44, 263-283.

476 Puma, M.J., Bose, S., Chon, S.Y., Cook, B.I., 2015. Assessing the evolving fragility of the global

477 food system. Environmental Research Letters 10, 024007.

478 Reardon, T., 2015. The hidden middle: the quiet revolution in the midstream of agrifood value 479 chains in developing countries. Oxford Review of Economic Policy 31, 45-63.

480 Reardon, T., Timmer, C.P., Minten, B., 2012. Supermarket revolution in Asia and emerging

481 development strategies to include small farmers. Proceedings of the National Academy of Sciences

482 USA 109, 12332-12337.

483 Renting, H., Rossing, W.A., Groot, J.C., Van der Ploeg, J.D., Laurent, C., Perraud, D., Stobbelaar, 484 D.J., Van Ittersum, M.K., 2009. Exploring multifunctional agriculture. A review of conceptual 485 approaches and prospects for an integrative transitional framework. Journal of environmental management 90 Suppl 2, S112-123.

487 Rodriguez-Loinaz, G., Alday, J.G., Onaindia, M., 2015. Multiple ecosystem services landscape 488 index: a tool for multifunctional landscapes conservation. Journal of environmental management $489147,152-163$.

490 Rossing, W.A.H., Modernel, P., Tittonell, P.A., 2014. Diversity in organic and agroecological 491 farming systems for mitigation of climate change impact, with examples from Latin America, in: 492 Fuhrer, J., Gregory, P. (Eds.), Climate change impact and adaptation in agricultural systems. CAB 493 International, Wallingford, pp. 69-87.

494 Standish, R.J., Hobbs, R.J., Mayfield, M.M., Bestelmeyer, B.T., Suding, K.N., Battaglia, L.L., 495 Eviner, V., Hawkes, C.V., Temperton, V.M., Cramer, V.A., Harris, J.A., Funk, J.L., Thomas, P.A., 496 2014. Resilience in ecology: Abstraction, distraction, or where the action is? Biological 497 Conservation 177, 43-51. 
Shen, J., Cui, Z., Miao, Y., Mi, G., Zhang, H., Fan, M., Zhang, C., Jiang, R., Zhang, W., Li, H.,

499 Chen, X., Li, X., Zhang, F., 2013. Transforming agriculture in China: From solely high yield to

500 both high yield and high resource use efficiency. Global Food Security 2, 1-8.

501 Smith, P., 2013. Delivering food security without increasing pressure on land. Global Food Security

$502 \quad 2,18-23$.

503 Stokstad, E., 2013. The War Against Weeds Down Under. Science 341, 734-736.

504 Strassburg, B.B.N., Latawiec, A.E., Barioni, L.G., Nobre, C.A., da Silva, V.P., Valentim, J.F.,

505 Vianna, M., Assad, E.D., 2014. When enough should be enough: Improving the use of current

506 agricultural lands could meet production demands and spare natural habitats in Brazil. Global

507 Environmental Change 28, 84-97.

508 Suweis, S., Carr, J.A., Maritan, A., Rinaldo, A., D’Odorico, P., 2015. Resilience and reactivity of

509 global food security. Proceedings of the National Academy of Sciences 112, 6902-6907.

510 Tscharntke, T., Klein, A.M., Kruess, A., Steffan-Dewenter, I., Thies, C., 2005. Landscape

511 perspectives on agricultural intensification and biodiversity - ecosystem service management.

512 Ecology Letters 8, 857-874.

513 Wheeler, T., von Braun, J., 2013. Climate Change Impacts on Global Food Security. Science 341, $514 \quad 508-513$.

515 Yachi, S., Loreau, M., 1999. Biodiversity and ecosystem productivity in a fluctuating environment:

516 The insurance hypothesis. Proceedings of the National Academy of Sciences of the United States of 517 America 96, 1463-1468. 
522 The term resilience is used in a variety of contexts but can often be vaguely defined and

523 difficult to quantify. In ecological systems resilience is described as the ability of a system

524 to absorb changes in state variables and so persist after a disturbance (Holling, 1973). In

525 social-ecological systems, such as agriculture, resilience can be defined as the ability of the

526 system to withstand stress factors while maintaining productivity, and the capacity to learn

527 and adapt (Folke et al., 2010). Thresholds of disturbance, at which an ecosystem switches

528 to another state, can be used as a measurement of resilience (Standish et al., 2014). Here we

529 talk about resilience in terms of production variability, and the ability of agro-ecosystems to

530 maintain stability in production levels even in the face of disturbances. The replacement of

531 ecosystem services with artificial inputs such as pesticides, fertilisers, and irrigation is one

532 way to reduce production variability in the short-term. However, these practices come with

533 a range of environmental externalities (Pretty et al., 2001) that eventually lead to negative

534 feedbacks and ultimately a reduction in productivity. Allison \& Hobbs (2004) use land-use

535 change in the Western Australian agricultural region as an example of how you can apply a

536 framework based on resilience theory to examine capacity for change and renewal to a

537 large-scale social-ecological system. More recently resilience thinking is being applied

538 real-world species conservation and ecosystem management decisions.

540 Text box 2. What does a resilient global food supply system look like?

541 For our food supply system to be "resilient" it must be able to withstand shocks, or recover

542 quickly from those that occur (Holling, 1973). Food security is defined as when people, at

543 all times, have access to sufficient, safe, nutritious food to maintain a healthy and active life 
544 (FAO, 2008). A resilient food supply system is therefore critical for delivering food "at all

545 times". The recent global food price spikes have illustrated that the food supply system we

546 currently rely on is fragile (Berazneva and Lee, 2013; Galtier, 2013) and this leads to

547 transitory periods of food insecurity for some, and chronic food insecurity issues for others.

548 At the global-level our food supply system is vulnerable to self-propagating disruptions due

549 to the fact that many countries rely on imports for staple foods and often will stop exporting

550 to other countries during a crisis to protect domestic supply (Puma et al., 2015). One way to

551 increase resilience in this context is to increase redundancy at the production level. If

552 production of certain commodities are interrupted in one region, other regions can

553 potentially make up for the losses. A second way is to reduce the risk of wide-scale

554 production losses due to extreme weather, pest outbreaks, or other events. Whilst food

555 retailers cannot stop such events they can help to ensure that agricultural landscapes are

556 managed in such a way to improve robustness to these shocks. Often these management

557 interventions (Table 1) need to be implemented at the landscape-level to achieve the

558 desired outcome. Resilience is one component of sustainability in this context. A discussion

559 of the inter-connectedness of these two concepts is beyond the scope of this article,

560 however we do observe that there is a strong relationship between management practices

561 aimed at improving sustainability and those that help build resilience in production

562 landscapes. 
564 Table 1. Examples of intervention strategies that may be used by stakeholders in response

565 to the 10 recommendations made above to improve resilience in the food supply chain. The

566 second column highlights the potential threats that could be minimized using the

567 intervention strategies outlined in the third column.

\begin{tabular}{|c|c|c|}
\hline Recommendation & $\begin{array}{l}\text { Threats or negative } \\
\text { changes }\end{array}$ & Examples of interventions to increase resilience \\
\hline $\begin{array}{l}\text { 1. Maintain and } \\
\text { restore soil } \\
\text { resources }\end{array}$ & $\begin{array}{l}\text { Loss of productive } \\
\text { land due to erosion } \\
\text { and salinity, yield } \\
\text { losses from crop } \\
\text { disease owing to } \\
\text { reduction in microbial } \\
\text { diversity needed for } \\
\text { pathogen suppressive } \\
\text { soils. }\end{array}$ & $\begin{array}{l}\text { Apply minimum or conservation tillage and other interventions } \\
\text { that build soil organic matter. } \\
\text { Repair degraded soils via re-vegetation initiatives, green } \\
\text { manures and application of organic matter. } \\
\text { Reduce soil erosion by maintaining year-round plant cover } \\
\text { (e.g. cover crops, wind breaks). } \\
\text { Use precision agriculture to ensure nutrient inputs/irrigation } \\
\text { are matched to the conditions and crop requirements. }\end{array}$ \\
\hline $\begin{array}{l}\text { 2. Protect water } \\
\text { resources }\end{array}$ & $\begin{array}{l}\text { Production losses } \\
\text { from insufficient } \\
\text { water supply for } \\
\text { crops, food } \\
\text { contamination from } \\
\text { microbial movement } \\
\text { in water, and } \\
\text { groundwater } \\
\text { pollutants. }\end{array}$ & $\begin{array}{l}\text { Match crops to water availability. } \\
\text { Manage soils and habitats to hold water, prevent water loss and } \\
\text { mitigate pollution. } \\
\text { Build infrastructure for holding and distributing water (e.g. } \\
\text { improved irrigation channels, drip systems). } \\
\text { Protect riparian corridors by implementing spray buffers, re- } \\
\text { vegetation, and fencing from livestock. }\end{array}$ \\
\hline $\begin{array}{l}\text { 3. Remove } \\
\text { marginal land } \\
\text { from high-input } \\
\text { production }\end{array}$ & $\begin{array}{l}\text { Loss of customers, } \\
\text { shift of customers to } \\
\text { other food supply } \\
\text { chains. }\end{array}$ & $\begin{array}{l}\text { Invest in conservation interventions - like habitat restoration, } \\
\text { traditional farming on non-productive land and in strategies for } \\
\text { integrating these interventions across the landscape or within } \\
\text { multifunctional landscapes. } \\
\text { Financially support conservation interventions aimed at iconic } \\
\text { farmland species and habitats (e.g. traditionally managed } \\
\text { grasslands). In some contexts low-intensity farming can } \\
\text { support biodiversity conservation. } \\
\text { Develop habitat conservation interventions that also support } \\
\text { the provision of ecosystem services. } \\
\text { Improve guidelines on land tenure in marginal lands such that } \\
\text { farmers have security to make environmentally sustainable } \\
\text { investments (i.e., support mobility). }\end{array}$ \\
\hline $\begin{array}{l}\text { 4. Use } \\
\text { agrochemicals } \\
\text { judiciously }\end{array}$ & $\begin{array}{l}\text { Pesticide resistance, } \\
\text { loss of natural pest } \\
\text { control, unacceptable } \\
\text { level of residues on } \\
\text { food. } \\
\text { High inorganic } \\
\text { fertilizer prices. }\end{array}$ & $\begin{array}{l}\text { Encourage farmers to use the appropriate quality and quantity } \\
\text { of agrochemicals. } \\
\text { Provide training and support for integrated pest management } \\
\text { and area-wide management strategies. } \\
\text { Interventions to enhance or maintain biodiversity-mediated } \\
\text { pest control, such as hedgerows, perennial non-crop habitat in } \\
\text { farming landscapes. } \\
\text { Educate consumers to recognize and accept cosmetic damage } \\
\text { to fresh produce and to focus more on the health and } \\
\text { environmental aspects of food. }\end{array}$ \\
\hline 5. Encourage & Dwindling or & Encourage farm businesses to produce a diversity of crop types \\
\hline
\end{tabular}


landscape-scale
diversification

6. Encourage
sustainable
livestock
management
practices

7. Identify and prepare for the products of the future

\section{Support farmers of the future}

\section{Identify products that are produced in high-risk regions}

10. Identify
products that
have significant
and costly
environmental
externalities

unsustainable supplies of synthetic chemical inputs.

Increasing threats from pest and disease outbreaks in homogenous landscapes. Livestock production becomes prohibitively costly through thresholds such as antibiotic resistance, pasture loss, or increased cost of imported feed.

Our current products are not well suited to future environmental and societal conditions.

Farming is not considered an attractive lifestyle or career path, changing demographic trends in many rural areas that we don't fully understand.

Disruption to supply by hurricanes, workers strikes, warfare, or production delays from worker shortages, and disease epidemics.

Production practices cause resource degradation that undermines stability of production. Product supply dependent on practices harmful to non-target organisms. Consumers avoid products because of and varieties.

Support farming systems that integrate livestock and crop production.

Use manure and leguminous cover crops to improve soils. Return waste/by-products from crops/food processing to livestock.

Encourage agro-forestry.

Encourage mixed forage systems.

Match stocking levels to available forage to prevent land degradation from erosion and over-grazing.

Support certification for humane livestock standards that avoid pathogenic conditions and lower disease incidence.

Encourage pastoral production through development of new forage mixes and livestock breeding programmes.

Develop new sustainable feeds that are locally derived.

Invest in Research, Development \& Extension activities around newly emerging products that have the potential to be sustainably produced under future environments.

Work with producers who have identified a potential new product to overcome marketing constraints.

Assist in the development of "demand forecasting" strategies for certain agricultural industries.

Articulate how these new products differ from existing products (e.g., perennial grain crops).

Develop policies for negotiating with producers that respects their role as farmers and land-stewards.

Ensure that the capability to continue farming in a region is present by sponsoring learning opportunities for champion farmers and promoting other education initiatives.

Be aware and knowledgeable of the local context and community attitudes and cultural differences when negotiating with farmers around interventions. Recognise and value the traditional knowledge of some producers.

Encourage sustainable land tenure agreements.

Initiate alternative sourcing for products from these regions, or identify and support local alternative products and incentivize long-term sustainable production practices that support local livelihoods and reduce vulnerability to risks.

Ensure all supply chains are evaluated by retailers and are transparent to consumers. True cost accounting. Identify products sourced from locations with hard trade-offs with the environment. Can these be sourced from a more desirable location or produced in a different way?

Encourage an increased use of seasonal local products and wean consumers off year round supplies of certain products. Circulate sustainability advisory lists (as is done with seafood) to indicate which products are the best choices, acceptable, and best to avoid. 
real or perceived

environmental and/or

social costs.

568

569

570

571

572 
573 Figure 1. The simplified food supply chain typically comprises many stakeholders, but few

574 organisations in the centre. However, where few organizations dominate a section of the

575 food supply chain, their mandates have the power to influence production practices (top

576 arrow) and consumer decisions (bottom arrow). The illustration (not to scale) is based on a

577 study by the Dutch Environmental Agency (Hoogervorst et al., 2012). Five wholesale

578 traders serve the 16.5 million Dutch consumers, therefore for every trader there is an

579 equivalent of 13,000 producers, 1,300 manufacturers and 300 distributors; there is one

580 trader for every five supermarket chains that retail through 880 supermarkets. We make 10

581 recommendations for ways in which these stakeholders can improve resilience of the food

582 supply chain.

583

584 Fig. 2. Ingredients for any product are frequently sourced from a wide variety of countries.

585 The provenance of ingredients for a chocolate bar produced in the UK is likely to extend

586 across 4 different continents, based on the major exporting countries for each ingredient.

587 Disrupted supply of any ingredient threatens the supply of the entire product, and is hence

588 an incentive for adopting a broadly adaptive resilience framework (see recommendations 9

589 and 10).

590 


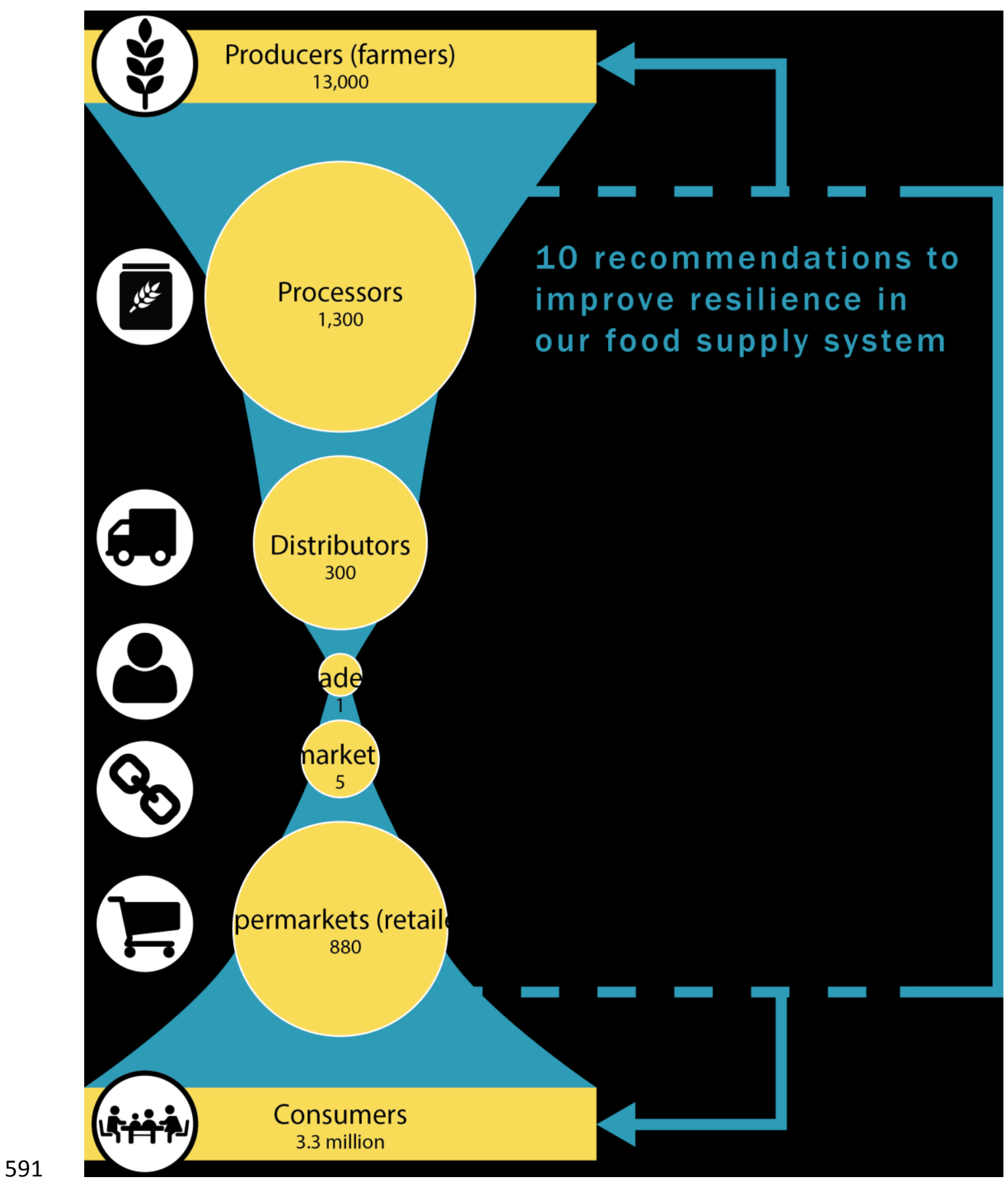

$592 \quad$ Figure 1.

593

594 


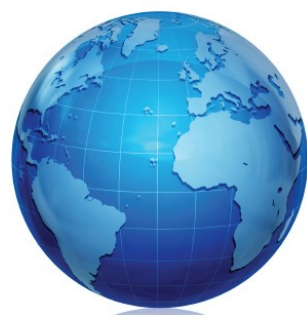

Europe

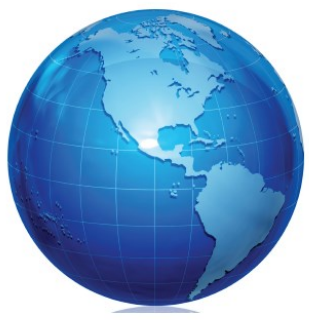

Canada, USA, Mexico, Brazil, Agentina

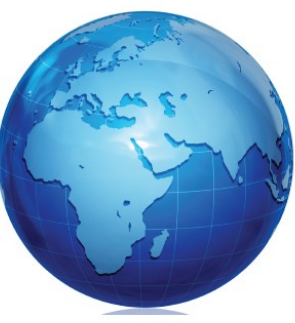

West Africa

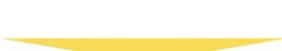

(1)

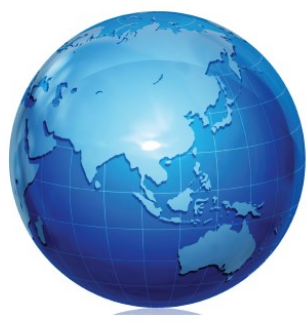

Australia, New Zealand, Thailand, Indonesia, Malaysia

(ㄱ)(1) (-)

\section{(i) (a) (-) $+\infty$}

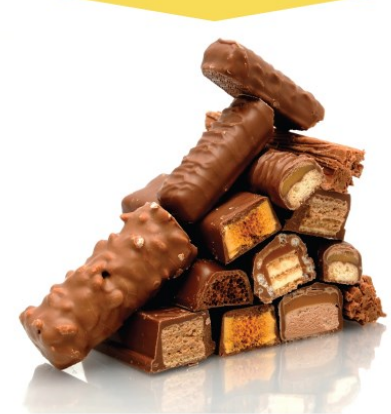

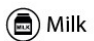
(- Cocoa
(6) Wheat flour
(a) Butter
(2) Sugar
(s) Salt
(ळ) Soy (protein)
(C) Palm oil (fat)
(4) Whey

600

Figure 2. 